\title{
THE FIRST HUNDRED YEARS (1883-1983)*
}

\author{
by R. A. RANKIN \\ (Received 19th October 1982)
}

\section{The early years}

This account of our Society is based to some extent on my Presidential address, which was given on 19 October 1977 and was devoted to the first fifty years.

In the latter half of the nineteenth century there was an upsurge of interest in mathematics that resulted in the foundation of a number of mathematical societies in different countries. The London Mathematical Society (1865), the Moscow Mathematical Society (1867), the Sociéte Mathématique de France (1873), the Edinburgh Mathematical Society (1883) and the New York (later American) Mathematical Society (1888) were all founded in this period. There had, of course, been earlier more local societies, such as the Spittalfields Mathematical Society, which flourished over a long period before becoming defunct, as well as one or two much older bodies, for example the Mathematische Gesellschaft in Hamburg (1690), which still survive.

In Great Britain top-ranking mathematicians and mathematical physicists, such as Cayley and Clerk Maxwell, could compare with any to be found outside these islands; however, at a lower level, the schools and universities were not producing comparable numbers of mathematicians able to advance their subject. Our sister society in London was founded at the suggestion of two students at University College, George Campbell De Morgan and Arthur Cooper Ranyard, with the blessing of the former's father, Professor Augustus De Morgan, who become its first president. It rapidly became a society of professional mathematicians. By contrast, the stimulus for the foundation of the Edinburgh Mathematical Society came from school teachers, and, in particular, from two mathematical masters at George Watson's College in Edinburgh, Alexander Yule Fraser (an M.A. of Aberdeen) and Andrew Jeffrey Gunion Barclay (an M.A. of Edinburgh). In conjunction with Dr Cargill Gilston Knott (1856-1922), who was then Assistant to the Professor of Natural Philosophy in Edinburgh University, they issued the following circular "to gentlemen in Edinburgh, in Cambridge and throughout Scotland generally whom they deemed likely to take an interest in such a Society".

*As part of the Centenary celebrations, the Committee invited Professor Rankin to write a history of the Society. 
EDINBURGH UNIVERSITY, JANUARY $23,1883$.

\section{Dear Sir,}

We, the undersigned, beg to call your attention to the following proposal, in the hope that you will find it in your power to give it your support:-

It is proposed to establish, primarily in connection with the University, a Society for the mutual improvement of its members in the Mathematical Sciences, pure and applied.

Amongst the methods by which this object might be attained may be mentioned: Reviews of works both British and Foreign, historical notes, discussion of new problems or new solutions, and comparison of the various systems of teaching in different countries, or any other means tending to the promotion of mathematical Education.

It is suggested that the Society be formed, in the first instance, of all those who shall give in their names on or before February 2, 1883, and who are (1) present or former students in either of the Advanced Mathematical Classes of Edinburgh University, (2) Honours Graduates in any of the British Universities, or (3) recognised Teachers of Mathematics; and that, after the above mentioned date, members be nominated and elected by ballot in the usual manner.

It may be added that Professors Tait and Chrystal have expressed themselves as highly favourable to the project, as one that may lead to important results.

If there are any of your friends who might take an interest in the Society, kindly inform them of its objects, and invite them to attend the Preliminary Meeting, to be held in the MATHEMATICAL CLASS ROOM here, on Friday, February 2, 1883, at Eight p.m., at which meeting your presence is respectively requested.

We are,

Yours faithfully,

CARgill G. Knott, D.Sc.(Edin.), F.R.S.E.

A. J. G. Barclay, M.A.(Edin.).

A. Y. Fraser, M.A.(Aberdeen).

As indicated in the letter, the preliminary meeting was held in the Mathematics Class Room, Edinburgh University, on Friday, 2nd February 1883, at 8 p.m. with Dr Knott in the chair. To quote from the minutes: "The Chairman, in his introductory remarks, mentioned that Professor P. G. Tait (Professor of Natural Philosophy at Edinburgh University) had suggested that the Society regard itself as the resuscitation of the Physico-Mathematical Society, which had led a vigorous existence during the years 1836-39, had revived at subsequent intervals, but finally collapsed in 1850 , leaving behind it, however, a library, some fragmentary apparatus, and a ballot-box". It would be interesting to have further information about this former society.

This suggestion, however, was not taken up and those present at the meeting turned their attention to a series of eight motions setting up the Edinburgh Mathematical 
Society, its aim being the mutual improvement of its members in the mathematical sciences, pure and applied.

The first officers of the Society were elected, Mr (later Dr) John Sturgeon Mackay (1843-1914) being the first President. He was chief mathematical master at The Edinburgh Academy and was an able mathematician with a scholary interest in the early Greek geometers. It was agreed that the Society should consist of Ordinary and Honorary Members, the only restriction on the former being that they should be proposed and seconded at one ordinary meeting and balloted for at the next.

One motion that was carried unanimously was that Professor Tait and Professor Chrystal (his colleague in the chair of mathematics at Edinburgh University) be elected Honorary Members. These two distinguished gentlemen (see Section 5) were, accordingly, our first Honorary Members. The next motion, which was merely agreed to, rather than carried unanimously, was that the professors of pure and applied mathematics in the other Scottish universities be invited to become Honorary Members. However, this motion was not pursued, since its proposers were not officers of the Society and the rules agreed at the second meeting of the Society restricted the proposers of such motions, as they do today, to members of the Committee. Nevertheless, at subsequent meetings Sir William Thomson (later Lord Kelvin) and Professor Charles Niven, Professor of Natural Philosophy at Aberdeen University, were elected Honorary Members.

It is interesting that school teachers rather than university staff took the leading part in the foundation of the Society. As Honorary Members, Professors Tait and Chrystal were not, of course; eligible as officers and the first professor to become President was James Edward Aloysius Steggall (1855-1935), who was Professor at University College, Dundee, Of the ten first Presidents seven were school teachers, while three were members of staff of universities; in contrast, the ten most recent Presidents have all been University Lecturers or Professors. Moreover, during the last thirty years only one President has not held a University appointment, and he joined the staff of a University immediately afterwards. The total number of Ordinary Members admitted at the first ordinary meeting of the Society in March 1883 was 51 . By the end of the first session 58 persons had become members of the Society. Of these 15 had a university connexion, including five from Cambridge, but about 40 were teachers, of whom five came from George Watson's, and one (R. T. Omand) was the director of the observatory on the summit of Ben Nevis. Over the years the percentage of university members has, of course, increased; however, as late as 1926, just before the second series of the Proceedings was instituted, their percentage had only risen from $26 \%$ to $36 \%$. The present (1982) membership of the Society is about 300 .

At the first meeting Professor Chrystal gave an address on "Present Fields of Mathematical Research". It may be of interest to list the titles of other talks given during the first session:

The triangle and its six inscribed circles (J. S. Mackay).

The nine-point circle (D. Munn).

New proof of Professor Tait's problem of arrangement (T. Muir).

Fundamental notions of the differential calculus (A. Y. Fraser).

Plücker's first equation concerning the singularities of curves (C. G. Knott). 
Some notes on quaternions (C. G. Knott).

Some theorems relating to the radical axes of circles (D. Munn).

These illustrate the preponderance of geometrical subjects during the early years of the Society. The early volumes of the Proceedings usually contained extensive appendices displaying geometrical figures, which would nowadays be very expensive to print.

The state of mathematics in Scotland at the time of the Society's foundation can be judged from the admirable and hard-hitting address given on 8 February 1884 by our second president Thomas Muir (1844-1934), who was at that time mathematical master at Glasgow High School. A graduate of Glasgow he had previously served as an Assistant to Professor Blackburn there and had also spent some time in continental universities. In 1892 he went out to Cape Town as Superintendent-General of Education, and spent the rest of his life there. From 1878 until his death he concerned himself with determinants and their history, a subject on which his books and papers, of which he published 307, are still the leading authority. He was elected a member of the Royal Society in 1900 and knighted in 1915.

Muir's presidential address, entitled "The Promotion of Research; with Special Reference to the Present State of the Scottish Universities and Secondary Schools", was privately printed by Alexander Gardiner of Paisley and is to be found in some libraries bound up with Volume 2 of the Proceedings. Great changes have taken place in universities and schools during the last hundred years, but even up till the Second World War much of what he wrote in 1884 was still to some extent relevant. As an example, I quote:

A Scotch University student who has a special taste for mathematics, and has come to the University to develop that taste, has usually something like the following career: Of the two or three mathematical classes taught in the University, he very probably enters the highest. There he obtains a knowledge of Synthetic and Analytical Conics, the elements of the Differential Calculus, and, it may be, of the Integral Calculus as well. He knows there is no hope for him if he does not take his Master of Arts degree, and he gives his attention to Classics and Mental Philosophy with this end in view, continuing by himself his reading in Mathematics as far as it may be possible to do so. In time he graduates: this entitles him to compete for a scholarship: he competes, and is successful, leaves for Cambridge, and his University knows him no more. Probably in the newspapers we observe that Mr. Donald Scott of a certain northern university has gained an open scholarship at Johnshouse, and the competition having been between him and a number of young men fresh from the English public schools, we are gratified accordingly with his startling success. Gentlemen, I put it to you, if this is a thing for us as Scotsmen to be altogether proud of. When in these cases a young Scotch student competing with English students of the same age gains a scholarship, there may be cause for gratulation: but the Scotsman who glories in the part his Universities play in the matter glories in his own shame. Is it really past hoping for that all this may yet be changed?

Muir was, of course, well aware of the deficiencies of the Cambridge coaching and examination system; after all these had been referred to by Augustus De Morgan in his 
presidential address in 1865 to the London Mathematical Society, of which Muir was a member. That was not the point at issue. What was relevant was that the "three years' course of mathematical drill at Cambridge", whether "well planned or ill planned", was to be "got nowhere else, certainly not in Scotland".

In 1884 University Lecturers scarcely existed. In Mathematics the sole professor might be aided by one or two Assistants with whose help he could only hope to cover a fraction of the subject. Time for research would take a low place in face of the more urgent demands of teaching and administration. Muir contrasted this unfavourably with the situation in Germany, where one university might have more professors of mathematics than existed in all the Scottish universities.

\section{Meeting places and times}

The Society now meets regularly in all eight Scottish Universities and joint meetings with the London Mathematical Society have been held in Edinburgh and Newcastle.

During its first two sessions the Society met in Edinburgh University, but moved in the autumn of 1884 to the Edinburgh Institution in Queen Street. This I take to be the precursor of the present Melville College, known affectionately during my school days as "Stution". This was the ordinary venue of meetings until June 1913, when the Society returned to Edinburgh University. The first meeting outside Edinburgh was held in March 1900 in the Glasgow Philosophical Society's rooms, during the presidency of $R$. F. Muirhead, who was a Glasgow man. Annual meetings in May or March of each year were held thereafter from 1901 to 1905 in the United Free Church College in Glasgow, later known as Trinity College. From 1906 till 1912 the annual Glasgow meeting was held in the Glasgow and West of Scotland Technical College (which evolved into the present University of Strathclyde). Thereafter from 1913 until 1931, once and latterly twice a year, meetings were held in the Mathematics Class Room of the University of Glasgow.

The move to Glasgow University was made shortly after Professor George A. Gibson's translation from the chair in the College to the chair in the University. Gibson's connexion with the Society goes back to its very early years (he was admitted in February 1884), but his predecessor in Glasgow, William Jack, although elected an Honorary Member in 1902, seems to have taken little interest in the Society. The billets advertising the Glasgow meetings are of interest, since from 1912 at the last meeting in the Royal Technical College until the last meeting in the University of Glasgow in 1931 they bear the invitation: Professor and Mrs Gibson (later Professor and Mrs MacRobert) "At Home", 10 The University. This pleasant custom was revived briefly at the time of the Glasgow meeting on 30 May 1980. I shall explain later why these Glasgow meetings ended abruptly in 1931 and did not resume until 1957.

The Society first began to meet annually in St Andrews in 1922. Its first meeting in Dundee took place in 1930 during Professor Steggall's last year of office as President. The first meeting in Aberdeen was in 1937.

Except for meetings in St Andrews (and until recently in Aberdeen), which are held on a Saturday, ordinary meetings have, since the foundation of the Society, been normally held on Friday evenings. Initially meetings began at 8 p.m. but over the years 
there has been a gradual movement to earlier times and the main lecture is now generally given in the late afternoon.

During the 1939-1945 war, meetings were usually held on Saturday mornings in Edinburgh. In both world wars there was, naturally, some curtailment of the Society's activities and for this reason, during the sessions beginning in 1917, 1939 and 1943, no changes were made in the offices of President and Vice-President.

\section{Publications}

When the Society was founded, it was the general practice for mathematical societies to print papers read at meetings. During its first session the Edinburgh Mathematical Society had not enough money to do this, and so copies of papers read were deposited with the Secretary. During the second session the Society resolved to print its proceedings in whole or in abstract, so that Volume 2 of the Proceedings was the first to be published and appeared in 1884. It was not until 1894 that Volume 1, covering the first session, appeared. It contains J. S. Mackay's paper on the six scribed circles of the triangle. This paper (uncut until I examined it in the Glasgow Departmental Library copy) occupies 124 pages and contains 72 figures printed on 24 pull-out sheets. Even so, it forms only part of the author's work on the subject.

The early volumes published by the Society are, accordingly, Proceedings of the Society in the strict sense of that word. The papers presented were in nearly all cases written by members of the Society, although occasionally the work of some other mathematician might be read. For example, P. G. Tait was interested in determining the form of a certain curve arising in the motion of a device described by De Morgan and known as Milner's Lamp. For this purpose he consulted Cayley, whose paper "On a differential equation and the construction of Milner's Lamp" appeared in Volume 5.

The subjects discussed in these early papers cover a wide range, but with a preponderance of Euclidean geometry. There are several articles on historical and pedagogical points, including collections of mnemonics.

By 1909 it was felt that the more elementary and pedagogic articles should not appear in the Proceedings and, at Professor G. A. Gibson's suggestion, it was agreed "to issue at stated intervals a supplement to the Proceedings dealing with the teaching of Mathematics and Science, the supplement to be called 'Mathematical Notes, a review of Elementary Mathematics and Science, published by the Edinburgh Mathematical Society'". The first number appeared in April 1909. Succeeding parts have been issued at irregular intervals, some being published together with the Proceedings and some separately. The last number (No. 44) appeared in 1961.

In this connexion it is, I think, of interest to mention a controversy that took place between 1927 and 1931 concerning the Society's publications. Perhaps controversy is too strong a word, since the disagreements occurred within the Committee and, so far as I can discover from the minutes, did not surface in the meetings of the Society. Nevertheless, strong feelings were aroused that had not entirely subsided when I first came to Glasgow 29 years ago. As one might guess, the main protagonists were both very strong characters with very different personalities. Perhaps the only things they had in common were that they had been undergraduates at Trinity College, Cambridge, had been classed as Wranglers in the Mathematical Tripos and had an interest in the theory 
of special functions. It is possible that this last bond may have exacerbated their different points of view. The older of the two was, of course, the late Sir Edmund Whittaker (1873-1956), who was Professor of Mathematics at Edinburgh from 1912 to 1946. During a period of nearly 40 years Whittaker exerted a powerful influence on the affairs of the Society; see Section 5. The younger of the two was the late Professor Thomas M. MacRobert (1884-1962), who was Professor of Mathematics at Glasgow University from 1927 to 1954 .

To set the scene I mention that, whereas in the early years of its existence the Society's membership consisted predominantly of school teachers, the number of teacher members had slowly declined as the level of research papers and lectures rose. The Mathematical Notes had, of course, been set up to cater especially for teachers and to print expository and historical articles, but, by the late $1920 \mathrm{~s}$, it was felt by some that this was not enough.

In December 1927, Professor MacRobert outlined to the Committee a scheme he proposed to bring forward in greater detail at the next meeting. In essence his scheme was that the Proceedings should be retained for research papers, but that the Society should publish in place of the Mathematical Notes a new periodical, to be called the Journal of the Edinburgh Mathematical Society, which would contain articles on History, Methods of Teaching, Notes, Discussions on Elementary Mathematics, etc. At the following meeting these proposals were discussed and agreed, although the proposed method of financing them was not accepted. At a subsequent meeting in May 1928, the Committee went further and agreed to start printing a first part of the Journal in its new form.

What happened after that is unrecorded since the matter is not referred to in either the minutes of the Society or those of the Committee until over two years later when, in July 1930, the Committee formed a subcommittee to update the Society's rules and make mention in them of the Society's publications. It was then agreed to expand the Mathematical Notes, and a change of name to the Journal of the Edinburgh Mathematical Society was again suggested.

From this point onwards the Committee appears to have divided into a pro-Journal and an anti-Journal party. Some members objected to the title Journal of the Edinburgh Mathematical Society on the grounds that it would clash with the recently founded Journal of the London Mathematical Society and other names were suggested such as Bulletin of the Edinburgh Mathematical Society and Scottish Mathematical Journal. The latter found most favour and appeared in a draft set of rules that later went before the Society, although those rules that concerned publications were never discussed by the Society at ordinary meetings but were always deferred.

On the anti-Journal side the view was expressed that the Society should in future become a research society and that the Glasgow Mathematical Association should be left to provide for those whose main interest was in pedagogic matters. It was claimed that in this way the Society was more likely to receive grants from the Royal Society. However, by this time the Secretary had received a letter from Professor MacRobert, who stated that he felt so much out of sympathy with the policy of the rest of the Committee that he felt impelled to resign from the Committee. He remained a member of the Society, but no further meetings of the Society were held in Glasgow for more than twenty years. 
The anti-journalists had won. To complete their victory they needed to dispose of the Mathematical Notes and the proposed Journal, but this proved to be more difficult. The editor of the Notes, Mr. William Arthur-a much respected member of the Glasgow staff-was asked to approach the Glasgow Mathematical Association to see whether they could assume responsibility, and he agreed to do so. However at their next meeting the Committee was informed that the Association had declined and that Mr. Arthur had resigned both from the Committee and from the editorship of the Notes. As a last resort approaches were made to the Educational Institute of Scotland suggesting that they might make themselves responsible for publishing the Notes, but these were unsuccessful. Accordingly, the final outcome was that, after four years of discussion, no change was made in the Society's publications and the Proceedings and the Notes continued to appear as before. It may be of interest to observe that five years later in 1936 the Glasgow Mathematical Association did commence publication of a periodical devoted to historical and pedagogical matters, called the Journal of the Glasgow Mathematical Association. This survived until 1953.

After a lapse of over fifty years, when one looks back at this small ripple in the even tenor of the affairs of the Society, one cannot help feeling that the proposal to establish a journal for historical and pedagogical matters was a useful and imaginative idea, which would have enhanced the reputation of the Society without detracting from the research pretensions of the Proceedings. With hindsight one suspects that the most cogent argument against the Journal was one, which, if it was made at the time, is not recorded in the minutes, namely the shortage of suitable high quality material, which ultimately caused the demise of the Mathematical Notes as well as of the Glasgow Journal.

It may be of interest to mention that the possibility of an amalgamation of the Edinburgh Proceedings with the Proceedings of the Glasgow Mathematical Association (now the Glasgow Mathematical Journal) to form a new Scottish Mathematical Journal was discussed in 1965, the view being that such a journal would carry greater prestige than either of its constituents since it would be of greater size and might appear more frequently. For a variety of reasons this proposal was not taken up, largely because it would have cut by about half the mathematical journals received under exchange agreements by the Glasgow and Edinburgh University Libraries.

The early volumes of the Proceedings were slim and were issued annually as single parts after the close of each session. Until 1907 the communications were printed, in full or by title, in the order in which they were delivered at the successive meetings of the Society. Gradually the number of contributions made at each meeting decreased. At an intermediate stage, for example, there might be one full hour's lecture accompanied by two or three papers read by title. Ultimately the current practice obtained whereby, at the majority of meetings, there is a single lecture, which need not necessarily be embodied in a paper submitted to the Society for publication.

By the middle 1920s it was felt that the size of page used was too small and a second series of the Proceedings was begun in 1927. Each volume of the new series generally consisted of four parts, published over a period of two years. The wrappers of the parts were originally brown, but were changed to green in 1958; in that year also short book reviews were published for the first time. The number of parts appearing annually was increased from two to three in 1979 and from that date volumes have appeared 
annually. Although it is not mentioned in the minutes, an important reason for embarking on a second series must have been the wish to raise the level of the papers published, which, although it had risen considerably over the years, remained somewhat uneven. In this connexion it may be noted that the new Constitution of the Society adopted on 15 January 1932 contains for the first time the provision that every paper published must first have been submitted by the Editors to at least one referee of recognised authority, and reported upon favourably by him.

An interesting item from the Minutes of the Committee held on 7 November 1942 (but not referred to subsequently) records that, in response to an appeal that appeared the previous month in Nature, it was agreed that the Society's publications should be sent for perusal by mathematicians held as prisoners of war in prison camps in Great Britain.

The original annual subscription, which included the cost of the publications, was five shillings ( $£ 0.25)$. This rose to seven shillings and sixpence in 1885 and remained at that rate until 1919 when it became ten shillings. In 1954 it was raised to fifteen shillings and since 1958 there have been further more frequent increases as a result of inflation. The current annual subscription is $£ 11$.

\section{Colloquia}

When Whittaker came to the Edinburgh chair in 1912 after Chrystal's death he soon began to inject fresh vitality into his department. He instituted a mathematical laboratory, where various branches of numerical analysis were taught that had previously been offered systematically in no British university. From its inception the laboratory clearly supplied a very definite need and requests were received for a vacation course from persons unable to attend during the normal academic teaching terms. This demand resulted in the running of the first mathematical colloquium sponsored by the Society. It was held from 4-8 August 1913 in Edinburgh University. Three courses of five lectures each were given. A. W. Conway, who was Professor of Mathematical Physics at University College, Dublin, spoke on "The Theory of Relativity and the new Physical Ideas of Space and Time", Dr D. M. Y. Sommerville, who was then Lecturer in Mathematics at St Andrews, spoke on "Non-Euclidean Geometry and the Foundations of Geometry", while Whittaker himself lectured on "Practical harmonic analysis; an illustration of Mathematical Laboratory practice". The colloquium was a striking success, being attended by 77 participants from all over Great Britain. For their entertainment golf matches were arranged in the evenings and there were visits to the Zoological Gardens, the Census Office, and new laboratories at the University and in George Heriot's School.

A second short colloquium was held in Edinburgh in July 1914 immediately after the Napier Tercentenary Celebration organized by the Royal Society of Edinburgh. No details are recorded in the minutes, possibly because of the outbreak of war immediately thereafter. After the war, largely through the enthusiasm and drive of Herbert Westren Turnbull (1885-1961), who had been appointed to the Regius Chair of Mathematics in St Andrews in 1921, the Society's colloquia were resumed. The first meeting in St Andrews in 1926 set the pattern for future colloquia, which have been held there at regular intervals since then. Meetings usually occupy ten days during which a number of 
short courses are given on a wide spread of topics in pure and applied mathematics. Ample time is allowed for recreational activities and the colloquium usually includes a musical entertainment given by some of the participants. The weather, fortunately, has nearly always been fine. Early colloquia were attended by many school-teachers as well as by those working in universities, but the increasing specialization of mathematics has resulted in a sharp drop in the number of those in the former category and the introduction of more specialized lectures supplementing the general courses. Since 1926 colloquia have been held in 1930,1934, 1938, 1951, 1955, 1959, 1964 and at four year intervals thereafter. The fifteenth colloquium will doubtless be held in 1984 .

The Society has always had an interest in pedagogical matters. Before the 1914-19 war in May of three successive years 1911, 1912 and 1913 one-day Secondary Education Congresses were held in Glasgow, Edinburgh and Dundee, respectively, for those interested in the teaching of mathematics. At intervals since then Ordinary Meetings have been devoted to pedagogical subjects.

\section{Some notable personalities in the history of the Society}

As has been mentioned, Alexander Yule Fraser and Andrew Jeffrey Gunion Barclay were mathematical masters at George Watson's College at the time of the foundation of the Society. They became Presidents in 1889 and 1884, respectively. They both moved later to Glasgow, Fraser becoming headmaster of Allan Glen's School and Barclay chief mathematical master of Glasgow High School. Other Watsonians prominent in the Society's affairs were Jock Alison (1861-1952), a distinguished headmaster, who was President in 1892, and Donald Cameron McIntosh, who was Secretary for many years and President in 1905.

The Society's first two honorary members were most interesting and able men. Peter Guthrie Tait (1831-1901), who was a school-fellow of James Clerk Maxwell at Edinburgh Academy, was a distinguished Professor of Natural Philosophy with very wide interests. I suspect that today he is better known for his work on combinatorial topics, such as map colourings, and as a founder of the mathematical theory of knots, than for his work on physics. During his life-time he achieved considerable fame as the first person to study scientifically the flight of a golf ball. He demonstrated that the Magnus effect of underspin could greatly increase the range and time of flight of a driven ball. A story was told as a joke against the Professor that his son Freddie, who was a brilliant amateur golfer, had gone out and driven a ball 250 yards, which was further than the maximum range "proved" possible by his father. There were, however, no grounds for this, since Tait stated no maximum ranges for spinning golf balls. Tait was junior author with Sir William Thomson of the famous Mathematical Treatise on Natural Philosophy affectionately known as $T$ and $T^{\prime}$.

Until I read his obituary I had always imagined that Tait's colleague George Chrystal (1851-1911) was a pure mathematician with a main interest in algebra. In fact his chief interest was in electricity and magnetism, from an experimental as well as from a theoretical point of view. Like other Scottish professors at that time he acted as an inspector of schools and he was the originator of the Scottish Leaving Certificate examinations, Moreover, it is due to him that, over a long period of years until the recent establishment of sixth year studies, Mathematics was the one subject in which 
school pupils could be examined at a level beyond that of the Higher Grade. His experience in teaching mathematics in the University convinced him that "algebra, as we teach it, is neither an art nor a science, but an ill-digested farrago of rules whose object is the solution of examination problems". This led him to write his monumental treatise of nearly 1200 pages on Algebra, which appeared in two parts in 1886 and 1889, and had a powerful effect on the teaching of algebra in Great Britain and abroad. His aim was to develop the subject as a logical science. A shorter version, entitled Introduction to Algebra for the use of Secondary Schools and Technical Colleges, appeared in 1902. This was the textbook my father used when he was in Chrystal's first year class at Edinburgh University. I recall that, when I was a boy of fourteen, he offered me ten shillings (a considerable sum of money fifty years ago) if I would read the whole of it, but my stamina was not sufficient to enable me to do so.

Of the original members of the Society few can have given it greater service than its first Secretary, Cargill Gilston Knott (1856-1922), who served twice as President. When the Society began he was Assistant to Professor Tait, but at the end of the first session he left to become Professor of Physics at the Imperial University of Japan, where he remained for eight years. On his return in 1891 he was appointed to one of the first Lectureships in Edinburgh University and later become a Reader. He was an authority on magnetism and seismology and was responsible for conducting the magnetic survey of Japan. Later on he became General Secretary of the Royal Society of Edinburgh and was the editor of the Napier tercentenary volume and of the collected papers of $P$. G. Tait. In addition to his books and papers on physics he published a booklet of fourfigure mathematical tables which is still widely used; I recently came across a copy in the University of Alberta bookstore in Edmonton. In the years 1892-93 there raged a controversy between the advocates of quaternions and the supporters of vectors. Knott was a leading figure on the quaternion side in these arguments. As Sir Edmund Whittaker wrote in his obituary of Knott, Tait "had succeeded to the generalship of the quaternionites on the death of Hamilton and bequeathed it in turn to Knott".

One of the most faithful early members of the Society was George Alexander Gibson (1853-1931). He was elected a member in 1884, while he was Assistant to the Professor of Mathematics in Glasgow University, and became in 1895 Professor of Mathematics at the Glasgow and West of Scotland Technical College. He returned to Glasgow University as Professor in 1909, retiring in 1927. He was the author of books on calculus which were notable for their rigour at a time when this was the exception rather than the rule, but his main interest was the history of mathematics. The Proceedings contain numerous papers by him on these two subjects. He also took an active part in meetings devoted to the teaching of mathematics.

No account of the Society would be complete without considerable mention being made of Sir Edmund Taylor Whittaker, who has already been referred to in this article more than once. After ten years as a Fellow of Trinity College, Cambridge, he moved to Dublin in 1906 to take up the post of Royal Astronomer of Ireland. In 1912 he came to Edinburgh to succeed George Chrystal as Professor of Mathematics. He was a man of extremely wide interests in mathematics and mathematical physics and was the author of several influential books as well as of numerous research papers.

Whittaker's institution of a Mathematical Laboratory at Edinburgh University has already been mentioned. Perhaps an even more important innovation made by him after 
his appointment there was the institution of "research lectures" for staff, post-graduate students and visitors. In this respect he was far ahead of his colleagues in other British universities. I quote from Dr Martin's excellent obituary notice, published as part of a Whittaker Memorial Number in Volume 11 of our Proceedings:

These were given twice weekly, usually at three o'clock in the afternoon, and their principal aim was to bring into prominence topics suitable for original investigation. Their subject matter was related either to Whittaker's own researches at the time or to some important matter of contemporary interest. For instance, when Einstein first produced a unified field theory the lectures dealt with that theory while a course on spinors followed the publication by Cartan of his important book on the subject. Whittaker's ability to absorb and digest so much fresh mathematical work and to lecture on it term after term was truly remarkable. For it must be emphasized that his lecture notes were not just verbatim copies of the essential parts of the published papers on the subject, but contained what was almost a redevelopment of the subject by himself. His notes, incidentally, were written out in great detail and he wrote on the blackboard practically everything that he said. He wrote extremely fast but his writing was always legible. At the end of a lecture he may have been physically tired but he was certainly mentally exhilarated. The research room in the Mathematical Institute is a small homely lecture room with a fire-place at the back, and a few minutes before the end of Whittaker's lecture someone in the back row would put the kettle on the fire so that by four o'clock tea would be ready. Whittaker would then relax in his armchair by the fire, serenely happy with his colleagues and visitors around him, while the animated discussion which arose would cover anything from the lecture just given to academic affairs or religion. In this atmosphere Whittaker was in a most exhilarating form and the inspiration seemed to flow from him. Indeed, as far as research work is concerned, it is rather for his power of inspiring others than for his own work that he will long be remembered.

Whittaker took up the affairs of the Society with enthusiasm and as President and, for many years, a member of the Committee, exerted a strong influence. His efforts were always directed to the enhancement of the reputation of the Society as an organization for the promotion of mathematical research, as is evident from what has already been written regarding the Society's publications and colloquia.

The Society also owes a great debt to $H$. W. Turnbull, who has already been mentioned in connexion with the colloquia held in St. Andrews. His main interest as a young man was the theory of invariants, on which he gave a course of lectures to the 1926 meeting held there; this formed the basis of his well-known book The Theory of Determinants, Matrices, and Invariants, which appeared in 1928. It was under Turnbull's editorship that the second series of the Proceedings was begun in 1927 and it was largely due to his efforts that the second series became a mathematical journal of repute. Turnbull was a fine musician and an experienced mountaineer; he had served as President of the Scottish Mountaineering Club, in whose handbooks many of his climbs are recorded. In later life he became an authority on the history of mathematics and, after his retirement in 1950, he edited the correspondence of Isaac Newton on behalf of the Royal Society. He, his older colleague Professor J. E. A. Steggall of Dundee and Dr 
Robin Schlapp of Edinburgh are the only members of our Society who have served three times as President.

I conclude this section by mentioning a man who was a fine mathematician but less successful in a worldly sense than those referred to above.

Robert Franklin Muirhead (1861-1941) was a graduate of Glasgow and Cambridge Universities and spent some time at the University of Göttingen. He took a great interest in the Society and was twice President, in 1899 and again in 1909. He was elected an Honorary Member in 1912. He held lectureships in Glasgow and Birmingham for brief periods and tutorships in London, Edinburgh and Glasgow, but never held any permanent position worthy of his talents. It is possible that this may have been because of his outspoken views on home rule and socialism. In his latter years he was head of a coaching establishment, the Glasgow Tutorial College. I first heard of Muirhead forty years ago from my supervisor, the late Professor G. H. Hardy, who had a high opinion of Muirhead's abilities, and some of his work on convexity which is of interest to statisticians has recently come into greater prominence. Men like Muirhead, or his younger colleague John Dougall (1867-1960), who was President in 1925 , would easily have obtained university posts in the golden 25 years following the last war, but they lived in times, rather like those we have moved into recently, when appropriate positions were not available to everyone of ability.

\section{Presidents}

The following list gives the names of the 100 men and one woman who have held the office of President during its first hundred years. The apparent discrepancy is due to the fact that the first session was a short one from February to November 1883. The terms of office of Dr Mackay's successors run from October or November of the year stated for twelve months. A numeral 2 or 3 after a name denotes a second or third term of service as President.

$\begin{array}{ll}1883 & \text { John Sturgeon Mackay } \\ 1883 & \text { Thomas Muir } \\ 1884 & \text { Andrew Jeffrey Gunion Barclay } \\ 1885 & \text { Robert McNair Ferguson } \\ 1886 & \text { George Thom } \\ 1887 & \text { William James Macdonald } \\ 1888 & \text { George Alexander Gibson } \\ 1889 & \text { Alexander Yule Fraser } \\ 1890 & \text { Robert Edgar Allardice } \\ 1891 & \text { John Edward Aloysius Steggall } \\ 1892 & \text { John Alison } \\ 1893 & \text { Cargill Gilston Knott } \\ 1894 & \text { John McCowan } \\ 1895 & \text { William Peddie } \\ 1896 & \text { John Wilson } \\ 1897 & \text { John Brown Clerk } \\ 1898 & \text { Alexander Morgan } \\ 1899 & \text { Robert Franklin Muirhead } \\ 1900 & \text { John Watt Butters } \\ 1901 & \text { George Duthie } \\ 1902 & \text { John Alexander Third }\end{array}$

1903 Charles Tweedie

1904 William Leslie Thomson

1905 Donald Cameron McIntosh

1906 James Archibald

1907 William Anderson Lindsay

1908 Peter Pinkerton

1909 Robert Franklin Muirhead ${ }^{(2)}$

1910 John Turner

1911 Duncan McLaren Young Sommerville

1912 Alexander George Burgess

1913 John Miller

1914 Edmund Taylor Whittaker

1915 Alexander Durie Russell

1916 Peter Comrie

1917 Peter Comrie ${ }^{(2)}$

1918 Cargill Gilston Knott ${ }^{(2)}$

1919 Neil McArthur

1920 David Gibb

1921 Thomas Murray MacRobert

1922 Peter Ramsay

1923 Archibald Milne 


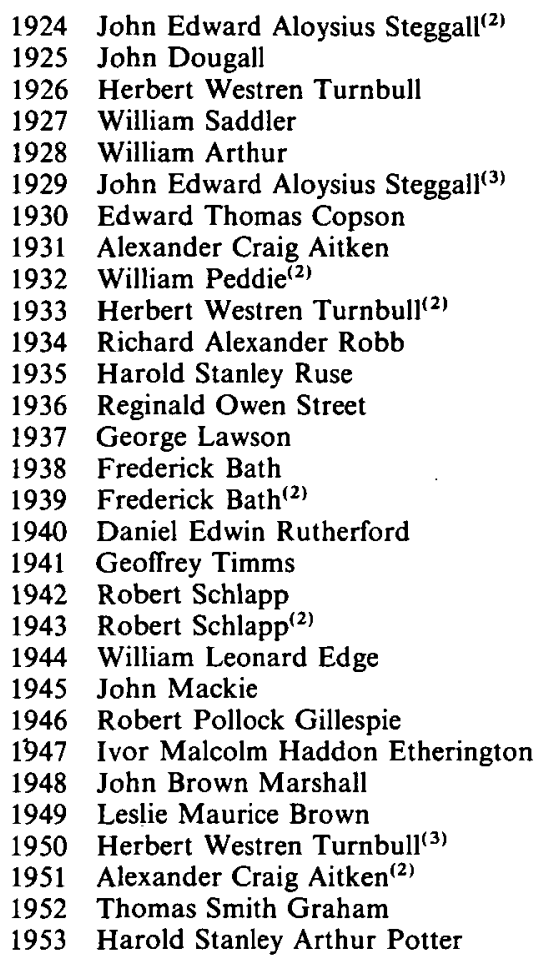

$\begin{array}{ll}1954 & \text { Edward Thomas Copson } \\ 1955 & \text { Raymond Smart } \\ 1956 & \text { Reginald Douglas Lord } \\ 1957 & \text { Robert Alexander Rankin } \\ 1958 & \text { John Meadows Jackson } \\ 1959 & \text { Ian Naismith Sneddon } \\ 1960 & \text { Daniel Martin } \\ 1961 & \text { Selwyn Read } \\ 1962 & \text { Donald Cecil Pack } \\ 1963 & \text { Daniel Edwin Rutherford } \\ 1964 & \text { Edward McWilliam Patterson } \\ 1965 & \text { Elizabeth Adam McHarg } \\ 1966 & \text { James Fulton } \\ 1967 & \text { Robert Pollock Gillespie } \\ 1968 & \text { Robert Schlapp } \\ 1969 & \text { John Hunter } \\ 1970 & \text { Willian Norrie Everitt } \\ 1971 & \text { Arthur Erdélyi } \\ 1972 & \text { William Derek Collins } \\ 1973 & \text { John Mackintosh Howie } \\ 1974 & \text { Robin John Knops } \\ 1975 & \text { David Alexander Ross Wallace } \\ 1976 & \text { Frank Featherstone Bonsall } \\ 1977 & \text { Arthur David Sands } \\ 1978 & \text { Robert Alexander Rankin }{ }^{(2)} \\ 1979 & \text { Thomas Scott Blyth } \\ 1980 & \text { John Duncan } \\ 1981 & \text { Gary Francis Roach } \\ 1982 & \text { Andrew George Mackie } \\ & \end{array}$

\section{Honorary secretaries}

The number of Secretaries was increased from one to two in 1971. Until 1975 a Secretary acted as chairman of the Committee. In that year, however, it was agreed that the President should take over this office.
1883
$1883-1888$
1888-1891
$1891-1896$
$1896-1899$
$1899-1904$
1904-1908
1908-1911
1911-1916
1916-1921
1912-1924
1924-1930
C. G. Knott
A. Y. Fraser
J. Alison
J. B. Clerk
J. W. Butters
D. C. McIntosh
P. Pinkerton
A. G. Burgess
P. Comrie
P. Ramsay
B. B. Baker
E. T. Copson

\section{Honorary treasurers}

$\begin{array}{ll}1930-1933 & \text { H. S. Ruse } \\ 1933-1938 & \text { I. M. H. Etherington } \\ 1938-1939 & \text { J. B. Marshall } \\ 1939-1944 & \text { I. M. H. Etherington } \\ 1944-1947 & \text { J. B. Marshall } \\ 1947-1953 & \text { R. Smart } \\ 1953-1960 & \text { J. Fulton } \\ 1960-1974 & \text { J. L. Mott } \\ 1971-1980 & \text { J. D. P. Meldrum } \\ 1974- & \text { T. A. Gillespie } \\ 1980- & \text { J. Martin }\end{array}$

1895-1898 D. Tweedie

1898-1899 F. Spence

1899-1905 J. Archibald

1905-1909 J. Turner 
1909-1915

1915-1927 E. M. Horsburgh

1927-1950 J. B. Lockhart

$1950-1953$ L. M. Brown

1953-1955

J. B. Marshall, Jr

\author{
1955-1963 W. M. Morrison \\ 1963-1972 G. MacKenzie \\ 1972-1976 G. F. Roach \\ 1976- A. C. McBride
}

\section{Honorary Members of the Edinburgh Mathematical Society}

1883 Peter Guthrie Tait (1831-1901), Professor of Natural Philosophy, Edinburgh University.

George Chrystal (1851-1911), Professor of Mathematics, Edinburgh University.

(Sir) William Thomson (later Lord Kelvin) (1824-1907), Professor of Natural Philosophy, Glasgow University.

Charles Niven (1845-1923), Professor of Natural Philosophy, Aberdeen University.

1894 John Sturgeon Mackay (1843-1914), first President of the Society, Mathematical Master, Edinburgh Academy.

1902 William Jack (1834-1924), Professor of Mathematics, Glasgow University.

George Alexander Gibson (1858-1930), former President of the Society, Professor of Mathematics, Royal Technical College, Glasgow, and later at Glasgow University.

1908 (Sir) Alfred George Greenhill (1847-1927), Professor of Mathematics, Artillery College, Woolwich.

1912 Robert Franklin Muirhead (1861-1941), twice President of the Society, Private Tutor, Glasgow.

1915 Charles Tweedie (1868-1925), former President of the Society, Lecturer in Mathematics, Edinburgh University.

1923 James Bolam (1839-1930), Principal Leith Nautical College.

1926 Henry Frederick Baker (1866-1956), Lowndean Professor of Astronomy and Geometry, Cambridge University.

George David Birkhoff (1884-1944), Professor of Mathematics, Harvard University.

1930 Tullio Levi-Civita (1873-1941), Professor of Mathematics, Rome University.

Herbert William Richmond (1863-1948), Fellow of King's College, Cambridge.

1933 (Sir) D'Arcy Wentworth Thompson (1861-1940), Professor of Natural History, St Andrews University.

1935 Ellice Martin Horsburgh (1870-1935), formerly Treasurer of the Society, Reader in Technical Mathematics, Edinburgh University.

1937 (Sir) Edmund Taylor Whittaker (1873-1956), former President of the Society and Professor of Mathematics, Edinburgh University.

1938 René Maurice Fréchet (1978-1973), Professor of Mathematics at the Sorbonne.

1946 Joseph Henry Maclagan-Wedderburn (1882-1948), former Vice-President of the Society and Professor of Mathematics, Princeton University.

1954 Luitzen Egbertus Jan Brouwer (1881-1966), Professor of Mathematics, University of Amsterdam.

(Sir) William Vallance Douglas Hodge (1903-1975), Lowndean Professor of Astronomy and Geometry, Cambridge University.

Herbert Westren Turnbull (1885-1961), three times President of the Society, Regius Professor of Mathematics, St Andrews University. 
1959 Harold Scott Macdonald Coxeter (1907-), Professor of Mathematics, Toronto University.

1967 Alexander Craig Aitken (1895-1967), twice President of the Society and formerly Professor of Mathematics, Edinburgh University.

1979 Edward Thomas Copson (1901-1980), twice President of the Society and formerly Regius Professor of Mathematics, St Andrews University.

Michael Francis Atiyah (1929-), Royal Society Research Professor, Oxford University.

1983 William Leonard Edge (1904-), former President of the Society, Professor Emeritus, Edinburgh University.

\section{The Sir Edmund Whittaker Memorial Prize}

After the death of Sir Edmund Whittaker in 1956 his son Dr J. M. Whittaker most generously gave on behalf of the Whittaker Family the sum of $£ 500$ to the Society to establish a prize for mathematical work in memory of his father. The main rules governing the award of the prize are as follows:

1. Prizes will be awarded for published work of particular merit in pure mathematics, applied mathematics, mathematical statistics or mathematical physics.

2. Normally one or more prizes of at least $£ 50$ will be awarded at four-yearly intervals, but an award may be withheld if no eligible work of sufficient merit has been published.

3. A candidate for a prize

(i) must be 35 years of age or less at the time of the award,

(ii) must either be a graduate of a Scottish University and/or have been engaged in postgraduate research in Scotland for at least three years.

No prizewinner shall be eligible thereafter.

The prize has now been awarded on six occasions, the winners being listed below:

1961 A. G. Mackie and A. H. Wallace

1965 J. B. McLeod

1970 D. J. S. Robinson

1973 A. M. Davie

1977 G. Brown and C. A. Stuart

1981 J. M. Ball

Department of Mathematics

University of Glasgow

Glasgow G12 8QW 